\title{
EFEKTIFITAS PROGRAM PEMBERIAN MAKANAN TAMBAHAN- PEMULIHAN PADA IBU HAMIL KURANG ENERGI KRONIK DI KOTA PALEMBANG
}

\author{
Rosyati Pastuty, Rochmah KM, Teti Herawati \\ Poltekkes Kemenkes Palembang Jurusan Kebidanan
}

\section{EFFECTIVENESS THE RECOVERY PROGRAM OF FOOD SUPLEMENT TOWARDS PREGNANCY WOMEN WITH CHRONIC ENERGY DEFICIENCY IN PALEMBANG CITY}

\begin{abstract}
Background: Chronic Energy Deficiency (CED )is condition which mother's lack nutrition for long time and impact for mother's and fetus health. Suplementary food recovery for CED pregnant women is one of efforts Palembang city Health office to resolve this problem. However, evaluation about this program until now. The aim this study to know effectiveness the suplementary food recovery for Chronic Energy Deficiency pregnant women program.

Methods: this study used Concurrent Mixed Metdhods design. Informants in qualitative research are 6 people, consist of 1 key informant (Health Department Health Care Staff) and 5 supporting informant (nutritionist Community Health Centers). Quantitative samples were all of pregnant women with size $<23.5$ cm upper arm Circumference whose accept supplementary recovery the number were 109 people. Data was analysed used Wilcoxon Test.

Result: All components of implementation Suplementary food recovery Programs in input, process and output has implemented according to the plan. Based on the analysist show there is a difference size of Superior Arm Circumference before and after Suplementary Feeding on CED during pregnancy with $p=$ $0.001(p<0.05)$.

Conclusion: Implementation of Suplementary Suplementary food recovery Programs for CED pregnant women in Palembang has implemented according to the plan. But need increasing some data in form report and need monitoring and output rating after implemented programs.
\end{abstract}

Keywords: Effectivenes, suplementary food recovery, programs

\begin{abstract}
ABSTRAK
Latar Belakang: Kekurangan Energi Kronis (KEK) merupakan keadaan dimana ibu mengalami kekurangan makanan dalam jangka waktu lama yang dapat mengakibatkan dampak kesehatan pada ibu dan janin. Pemberian Makanan Tambahan-Pemulihan pada ibu hamil KEK merupakan salah satu upaya Dinas Kesehatan Kota Palembang untuk mengatasi masalah tersebut. Namun, hingga saat ini belum ada evaluasi terhadap pelaksanaan program pemberian makanan tambahan dalam mengatasi KEK pada ibu hamil. Penelitian ini bertujuan untuk mengetahui efektivitas program Pemberian Makanan Tambahan-Pemulihan pada ibu hamil KEK di kota Palembang.

Metode: penelitian ini menggunakan Concurrent Mixed Method. Informan dalam penelitian Kualitatif sebanyak 6 orang, yang terdiri dari 1 informan utama (Staf Pelayanan Kesehatan Primer Departemen Kesehatan) dan 5 informan pendukung (petugas gizi di 5 Puskesmas). Sampel penelitian kuantitatif adalah semua ibu hamil dengan ukuran Lingkar Lengan Atas $<23,5 \mathrm{~cm}$ yang menerima makanan tambahan sebanyak 109 orang. Sedangkan analisis untuk mengetahui efektivitas program Pemberian Makanan Tambahan-Pemulihan pada ibu hamil KEK dengan menggunakan Wilcoxon Test.

Hasil: Semua komponen implementasi program Pemberian Makanan Tambahan-Pemulihan dari input, proses dan output telah dilaksanakan sesuai dengan rencana. Berdasarkan analisis Wilcoxon Test menunjukkan ada perbedaan ukuran Lingkar Lengan Atas sebelum dan sesudah Pemberian Makanan Tambahan-Pemulihan pada ibu hamil dengan $\mathrm{p}=0,001(\mathrm{p}<0,05)$.

Kesimpulan: Implementasi Program Pemberian Makanan Tambahan-Pemulihan pada ibu hamil di Palembang telah dilaksanakan sesuai dengan rencana. Tetapi perlu menambahkan beberapa data dalam laporan dan kerjasama dengan kader kesehatan untuk pemantauan dan penilai output setelah program dilaksanakan.
\end{abstract}

Alamat Koresponding: Rosyati Pastuty, Poltekkes Kemenkes Palembang Jurusan Kebidanan, Jl. Jend Sudirman km.3,5 Komplek RSUP dr Moh Hoesin Palembang email: rosytuti@yahoo.com 
Kata Kunci: Efektifitas, program, pemberian makanan tambahan-pemulihan

\section{PENDAHULUAN}

Salah satu indikator tercukupinya kebutuhan zat gizi ibu hamil dapat diketahui dari bertambahnya berat badan ibu setiap bulan. ${ }^{1}$ Status gizi yang memadai dan asupan makanan yang baik selama prakonsepsi dan kehamilan telah diakui sebagai kontributor utama untuk hasil kelahiran yang sehat. ${ }^{2}$ Status nutrisi pada wanita hamil, sangat berpengaruh terhadap pertumbuhan dan perkembangan janin saat dalam kandungan. ${ }^{3}$ Status nutrisi yang rendah berkaitan dengan masalah kekurangan gizi. Sebagai negara berkembang masalah kekurangan gizi masih menjadi masalah utama di masyarakat Indonesia. ${ }^{4}$ Salah satu masalah kekurangan gizi pada ibu hamil di Indonesia yaitu Kekurangan Energi Kronik. Pengertian Kekurangan Energi Kronik merupakan kurangnya asupan energi yang berlangsung lama atau kronik. $^{5,6}$ Ketika ibu hamil mengalami kekurangan gizi pada trimester terakhir maka cenderung akan melahirkan bayi dengan BBLR, hal ini dikarenakan pada masa ini janin akan tumbuh dengan sangat cepat dan terjadi penimbunan lemak. ${ }^{7}$ Prevalensi Berat Bayi Lahir Rendah (BBLR) di Kabupaten Situbondo meningkat dari 2,79\% pada tahun 2008 menjadi 5,85\% pada tahun 2014. Prevalensi tertinggi pada tahun 2015 ditemukan di Kecamatan Bungatan Situbondo (11\%). Kekurangan Energi Kronis meningkatkan risiko BBLR (OR=5,6; 95\% $\mathrm{CI}=1,41-22,57){ }^{8}$

Faktor-faktor yang berhubungan dengan KEK diantaranya adalah jumlah konsumsi energi dan jarak kehamilan. ${ }^{9}$ Ibu yang Kekurangan Energi Kronis seringkali memiliki anak yang kekurangan gizi. Kekurangan energi kronis pada ibu hamil di negara-negara berkembang bertanggung jawab untuk 1 dari 6 kasus dengan berat badan lahir rendah. ${ }^{10} 17 \%$ ibu hamil di pedesaan Ethiopia, menderita tingkat gizi suboptimal. Salah satu alasan utama adalah bahwa pengetahuan gizi ibu dan sikap gizi ibu perempuan pedesaan Ethiopia termasuk yang terendah dan termiskin di dunia. ${ }^{11}$

Angka prevalensi risiko KEK pada Wanita Usia Subur (WUS) di Indonesia sebesar $13,6 \%{ }^{12}$ Sedangkan berdasarkan peta kesehatan Indonesia, prevalensi ibu hamil KEK sebesar 16,8\%. Berdasarkan data Dinas Kesehatan Kota Palembang tahun 2015, jumlah ibu hamil KEK berjumlah $1.027 \mathrm{ibu}$ hamil. ${ }^{13}$ Upaya untuk meningkatkan status gizi ibu hamil KEK di Kota Palembang dengan Pemberian Makanan TambahanPemulihan (PMT-P) pada ibu hamil KEK. Setiap ibu hamil dengan ukuran LiLA $<23,5$ akan mendapatkan PMT-P berupa roti biskuit (sandwich) yang harus di konsumsi setiap hari 1 roti (100 gr) diberikan selama 90 hari. PMT-P diberikan sebagai tambahan makanan, bukan sebagai makanan pengganti sehari-hari. Kemenkes RI mendistribusikan program PMT dalam bentuk PMT pabrikan. Program ini diprioritaskan pada ibu hamil KEK berdasarkan ukuran LiLA $<23,5 \mathrm{~cm}$ terutama di wilayah Kabupaten/Kota yang mengalami rawan gizi. ${ }^{14}$

Tujuan penelitian untuk mengetahui efektifitas pelaksanaan program PMT-P pada Ibu hamil KEK di Kota Palembang. Efektifitas program PMT-P diukur berdasarkan pendekatan system berupa input, proses dan output. Output dari program PMT-P dilihat berdasarkan pertambahan kenaikan berat badan ibu atau perubahan ukuran LiLA setelah diberikan PMT-P selama 90 hari.

\section{METODE}

Jenis penelitian ini adalah Mixed Methods dengan metodologi penelitian Concurrent Mixed Methods. ${ }^{15}$ Analisis data kualitatif menggunakan content analysis yaitu data diperoleh dengan melakukan indepth interview terhadap 1 orang Staf Pelayanan Kesehatan Dasar Dinas Kesehatan 
Kota Palembang dan 5 orang petugas gizi di 5 puskesmas (Puskesmas 4 Ulu, Puskesmas Kertapati, Puskesmas Gandus, Puskesmas Makrayu dan Puskesmas Multiwahana) dan catatan lapangan hasil telaah dokumen. Pendekatan kualitatif pada penelitian untuk mendapatkan gambaran mengenai pelaksanaan program PMT pada Ibu hamil KEK, dengan menggunakan pendekatan sistem yaitu input, proses maupun output dari program PMT-P pada ibu hamil KEK di 5 puskesmas Kota Palembang.

Sedangkan data kuantitaif digunakan untuk mengetahui efektifitas PMT-P ibu hamil KEK terhadap perubahan status gizi yang dinilai dari ukuran LILA sebelum dan sesudah PMT-P diberikan pada 109 sampel dengan kriteria; semua ibu hamil KEK yang mendapatkan PMT-P selama 90 hari, dengan menggunakan Uji Wilcoxon.

\section{HASIL PENELITIAN Pendekatan Sistem}

Secara umum gambaran program PMT pada ibu hamil KEK dijelaskan dengan menggunakan pendekatan system yang dilakukan pada komponen input, proses dan output.

\section{a. Input}

Unsur-unsur yang diperhatikan dalam komponen program PMT-P pada ibu hamil KEK yang sudah dijalankan oleh program gizi Seksi Pelayanan Kesehatan Dasar Dinas Kesehatan Kota Palembang beserta petugas gizi yang ada di puskesmas Kota Palembang adalah:

1) Data

Sumber data pelaksanaan program Pemberian Makanan TambahanPemulihan ibu hamil KEK didapat dari laporan bulanan yang dikirim puskesmas.

2) Sumber Daya
Pelaksanaan program Pemberian Makanan Tambahan-Pemulihan ibu hamil KEK di Kota Palembang dilaksanakan oleh Seksi Pelayanan Kesehatan Dasar Dinas Kesehatan Kota Palembang beserta petugas gizi di puskesmas.

3) Sarana dan Prasarana

Untuk membantu pelaksanaan program Pemberian Makanan Tambahan-Pemulihan ibu hamil KEK di Kota Palembang, Seksi Pelayanan Kesehatan Dasar Dinas Kesehatan Kota Palembang dan petugas gizi di puskesmas masing-masing diberi 1 unit komputer dan printer.

4) Dana

Dana pelaksanaan program Pemberian Makanan TambahanPemulihan ibu hamil KEK di Kota Palembang bersumber dari anggaran APBN, APBD I dan APBD II.

5) Materi

Setiap ibu hamil KEK akan mendapatkan makanan tambahan berupa roti biskuit (sandwich) yang harus dikonsumsi setiap hari 1 roti (100 gr) diberikan selama 90 hari pada trimester akhir.

6) Sasaran

Sasaran program Pemberian Makanan Tambahan-Pemulihan ibu hamil KEK di Kota Palembang adalah semua ibu hamil yang mengalami KEK berdasarkan ukuran LILA <23,5 $\mathrm{cm}$ terutama di wilayah Kabupaten/Kota yang mengalami rawan gizi. 
Tabel 1.

Proporsi Ibu Hamil KEK Berdasarkan Usia di Kota Palembang

\begin{tabular}{lcllc}
\hline Usia Ibu & f & \% & Mean & Standar Deviasi \\
\hline$<20$ tahun & 10 & 9,2 & & 5,028 \\
$20-35$ tahun & 92 & 84,4 & 25,65 & \\
$>35$ tahun & 7 & 6,4 & & \\
\hline Jumlah & $\mathbf{1 0 9}$ & $\mathbf{1 0 0}$ & & \\
\hline
\end{tabular}

Berdasarkan hasil analisis Tabel 1, menunjukan bahwa sebagian besar $(84,4 \%)$ usia ibu hamil yang mendapatkan PMT-P pada kelompok

Tabel 2.

Proporsi Ibu Hamil KEK Berdasarkan Usia Kehamilan di Kota Palembang

\begin{tabular}{llllc}
\hline \multicolumn{1}{c}{ Usia Kehamilan } & f & \% & Mean & Standar Deviasi \\
\hline <13 minggu & 18 & 16,5 & & \\
13-27 minggu & 55 & 50,5 & 22,40 & 7,980 \\
$>27$ minggu & 36 & 33 & & \\
\hline Jumlah & $\mathbf{1 0 9}$ & $\mathbf{1 0 0}$ & & \\
\hline
\end{tabular}

Berdasarkan hasil analisis Tabel 2, menunjukan bahwa sebagian besar $(50,5 \%)$ usia kehamilan ibu yang mendapatkan PMT-P pada kelompok usia kehamilan 13-27 minggu. Rata-rata ibu hamil yang mendapatkan PMT-P pada usia kehamilan 22,4 minggu (Trimester II).

\section{b. Proses}

Hal-hal yang perlu diperhatikan dalam melakukan proses yaitu menilai perencanaan program untuk mengetahui target sasaran dari program PMT, pelaksanan program serta pengawasaan program apakah telah mencapai target yang ditetapkan, serta mengidentifikasi kendala dan masalah yang dihadapi dan pemecahannya.

\section{1) Perencanaan}

Perencanaan program gizi di

Dinas Kesehatan Kota Palembang dibuat berdasarkan:
a) Besaran masalah yang dihadapi.
b) Ketersediaan dana.
c) Ketersediaan sumber daya

usia 20-35 tahun. Rata-rata usia ibu hamil yang mendapatkan PMT-P adalah usia 25,6 tahun.
2) Pelaksanaan

Pelaksanaan program PMT-P pada ibu hamil KEK mengacu pada dokumen KAK (Kerangka Acuan Kegiatan) yang telah dibuat pada saat perencanaan. Kegiatan dilaksanakan selama 3 (tiga) bulan, (Agustus, September dan Oktober). Pemberian makanan tambahan pada ibu hamil diberikan dalam bentuk roti biskuit (sandwich).

3) Pengawasan dan Penilaian PMT ibu hamil KEK

Dalam pengawasan program PMT pada ibu hamil KEK, Staf Pelayanan Kesehatan Dasar Dinas Kesehatan Kota Palembang hanya sebatas menanyakan apakah makanan tambahan tersebut telah terdistribusi dengan lancar atau tidak.

Dalam pelaksanaannya petugas gizi di puskesmas tidak melakukan pengawasan secara khusus apakah PMT-P yang diberikan telah dikonsumsi sesuai 
aturan atau tidak. Pengawasan dan pemantauan dilakukan hanya ketika ibu hamil melakukan kunjungan ulang (untuk mengambil kembali produk PMT di puskesmas). Saat itulah petugas gizi memantau pertambahan berat badan atau pengukuran LILA ibu hamil tanpa menanyakan apakah PMT-P yang diberikan telah dikonsumsi sesuai aturan atau tidak.

\section{c. Output}

Setiap puskesmas di Kota Palembang melaporkan hasil program PMT pada Ibu Hamil ke Dinas Kesehatan Kota Palembang. Staf Pelayanan Kesehatan Dasar
Dinas Kesehatan Kota Palembang akan melaporkan hasil program PMT-P pada ibu hamil KEK ke Pemerintah Kota Palembang, serta Pemerintah Daerah Propinsi Sumatera Selatan, sebatas laporan akhir pendistribusian PMT-P pada ibu hamil KEK, dikarenakan dana program PMT berasal dari APBD I, APBD II dan APBN.

\section{Gambaran Efektifitas Program PMT-P Ibu Hamil KEK di Kota Palembang}

Gambaran efektifitas program PMT-P pada Ibu Hamil KEK dapat diketahui berdasarkan hasil analisis data dari 5 puskesmas di Kota Palembang berdasarkan penambahan ukuran LILA setelah pemberian PMT-P.

Tabel 3.

Efektifitas Program PMT-P pada Ibu Hamil KEK di Kota Palembang

\begin{tabular}{lcccc}
\hline \multicolumn{1}{c}{ Variabel } & $\mathbf{n}$ & $\begin{array}{c}\text { Median } \\
\text { (Minimum-Maksimum) }\end{array}$ & Rerata $\pm \boldsymbol{s . b}$ & $\boldsymbol{p}$ \\
\hline LILA Sebelum PMT-P & 109 & $22,0(20,0-23,5)$ & $22,08 \pm 0,97$ & 0,001 \\
LILA Setelah PMT-P & & $23,5(20,9-25,0)$ & $23,17 \pm 1.01$ &
\end{tabular}

Berdasarkan analisis data pada tabel 3, menunjukan bahwa ukuran LILA sebelum PMT-P adalah 20,0-20,5 cm. Sedangkan setelah diberikan PMT-P terjadi kenaikan menjadi 23,9-25,0 cm. Hasil Uji Wilcoxon menunjukan nilai significancy $0,001(p<0,05)$ dengan demikian dapat disimpulkan terdapat perbedaan yang bermakna ukuran LILA sebelum PMT-P dan setelah PMT-P pada Ibu Hamil KEK.

\section{PEMBHASAN}

Program PMT-P pada Ibu Hamil KEK bertujuan untuk meningkatkan status gizi ibu hamil gizi kurang terutama dari keluarga miskin. Hal ini sejalan dengan salah satu ketetapan Kemenkes RI mengenai acuan strategi penanggulangan masalah gizi makro khususnya pada ibu hamil dengan melakukan subsidi langsung berupa PMT-P. Berdasarkan ketetapan Kemenkes RI subsidi diberikan dalam bentuk dana untuk pemberian makanan tambahan kepada ibu hamil KEK. Namun pada pelaksanaannya Dinas Kesehatan Kota Palembang memberikan PMT-P pada ibu hamil KEK berupa roti biskuit (sandwich) setiap hari 1 roti (100 gr) diberikan selama 90 hari pada trimester akhir.

Pemberian makanan tambahan juga dilaksanakan oleh PT Pertamina EP Asset 3 Subang Field yang melakukan kegiatan CSR pendampingan untuk Program Pemberian Makanan Tambahan Pemulihan (PMT-P) kepada ibu hamil dan balita kurang gizi di wilayah Kecamatan Cilamaya Kulon dan Cilamaya Wetan, Kabupaten Karawang (UPTD Puskesmas Sukatani dan UPTD Puskesmas Pasirukem). Tujuan pelaksanaan program PMT-P adalah untuk memperbaiki status gizi dan kesehatan guna mengurangi kerentanan terhadap berbagai penyakit yang 
menyerang ibu hamil dan balita. Program ini berhasil mengurangi jumlah ibu hamil yang mengalami Kurang Energi Kronis (KEK) hingga $100 \%$ di UPTD Puskesmas Sukatani dan 60\% di UPTD Puskesmas Pasirukem. ${ }^{16}$

Penelitian tentang Survei Intervensi Ibu Hamil Kurang Energi Kronik (KEK) di Kecamatan Jatinangor meskipun hanya $36,3 \%$ ibu hamil yang mendapatkan pemberian makanan tambahan (PMT). Ibu yang telah diberikan konseling kesadaran gizi serta melakukan pemeriksaan rutin antenatal dapat meningkatkan perbaikan status gizi. ${ }^{17}$ Hal ini didukung oleh penelitian di China, bahwa kepatuhan untuk mengkonsumsi nutrisi yang direkomendasikan dengan penekanan khusus pada pendidikan mengenai gizi dapat mengurangi kesenjangan status gizi yang terjadi. ${ }^{18}$

Begitu juga penelitian di Bogor tentang pengaruh pemberian makanan tambahan terhadap konsumsi energy dan protein ibu hamil menunjukkan rata-rata tingkat kepatuhan konsumsi produk yang diberikan cukup tinggi yaitu 93\%. Tingkat kepatuhan konsumsi terhadap biskuit paling tinggi (94.0\%), kemudian diikuti susu (93.5\%) dan terakhir bihun (92.5\%). Tingginya tingkat kepatuhan konsumsi produk makanan dipengaruhi antara lain oleh variasi produk yang diberikan, sifat sensoris, dan juga keberhasilan dalam sosialisasi pada ibu hamil. Variasi produk yang diberikan meliputi susu coklat + biskuit susu, susu vanila + bihun, susu katuk + biskuit coklat, susu coklat + bihun dan susu vanila + biskuit keju. Banyaknya variasi produk yang diberikan dapat menurunkan unsur kebosanan/kejenuhan terhadap produk intervensi. $^{19}$

Langkah-langkah yang dilakukan dalam program PMT pada Ibu Hamil KEK adalah:

a. Identifikasi sasaran

Target sasaran ditentukan berdasarkan hasil antropometri (ukuran LILA <23,5 $\mathrm{cm}$ ) yang dilaksanakan langsung di lapangan dan berasal dari keluarga miskin. Dinas Kesehatan Kota Palembang mendapatkan data sasaran dari hasil laporan bulanan puskesmas.

b. Distribusi produk makanan tambahan diberikan oleh Seksi Pelayanan Kesehatan Dasar Dinas Kesehatan Kota Palembang ke petugas gizi di puskesmas. Selanjutnya petugas gizi bekerjasama dengan bagian KIA langsung kepada ibu hamil risiko KEK melalui petugas gizi di puskesmas, yang diambil langsung oleh ibu hamil saat berkunjung ke puskesmas untuk memeriksakan kehamilannya setiap bulan pada trimester akhir.

c. Evaluasi PMT-P; penggunaan dana, proses PMT-P dan perubahan status gizi.

Semua dana bantuan diberikan dalam bentuk roti biskuit (sandwich) kepada semua ibu hamil KEK yang sudah terdata. Evaluasi proses PMT-P hanya sebatas laporan bulanan ibu hamil KEK yang telah mendapatkan PMT-P dari puskesmas. Belum ada evaluasi tentang pendistribusian PMT-P dan keberhasilan PMT-P dalam meningkatkan status gizi ibu hamil.

Dinas Kesehatan Kota Palembang berfungsi sebagai perumusan kebijakan teknis di bidang perencanaan dan pelaksanaan program PMT-P pada Ibu Hamil KEK. Dinas Kesehatan juga berperan sebagai perumus kebijakan program PMT-P dan penyelenggara program PMT-P di wilayah Kota Palembang. Efektivitas program PMT-P dinilai dengan tiga penetapan, yaitu :

a. Pendekataan sumber dengan melihat efektivitas dari input yang terdiri dari data, sumber daya manusia, dana, sarana dan prasarana, materi, dan sasaran dari program PMT-P pada Ibu Hamil KEK.

b. Pendekatan proses dengan melihat efektivitas dari pelaksanaan program dari semua proses internal yang dilihat 
berupa proses perencanaan, pelaksanaan, pengawasan, dan evaluasi program PMT-P pada Ibu Hamil KEK.

c. Pendekatan sasaran dengan melihat efektivitas yang dipusatkan pada output dengan mengukur keberhasilan program untuk mencapai hasil (output) yang diharapkan dari program PMT pada Ibu Hamil KEK.

Efektivitas program PMT berdasarkan pendekatan sasaran dilihat dari output program PMT-P pada ibu hamil KEK. Efektivitas diukur berdasarkan pendekatan sasaran (goals approach) agar dapat mengukur keberhasilan untuk mencapai hasil (output) yang sesuai dengan rencana. Untuk mengetahui nilai output yang dihasilkan pada program PMT-P pada ibu hamil KEK dilakukan analisis data sekunder dengan pendekatan kuantitatif. Hal ini dilakukan untuk mengetahui seberapa besar efektifitas program PMT-P pada Ibu hamil KEK, dari bertambahnya ukuran LILA ibu hamil setelah pemberian makanan tambahan.

Dengan melihat hasil yang dicapai dapat diketahui apakah program PMT-P untuk penanganan kondisi KEK pada ibu hamil dapat dikatakan efektif atau tidak. Pertambahan ukuran LiLA ibu hamil dapat dijadikan sebagai prediksi berat bayi saat lahir. Namun data berat bayi saat lahir belum dicantumkan pada laporan PMT-P pada Ibu Hamil KEK sehingga belum dapat diketahui apakah pemberian PMT-P pada ibu hamil KEK juga dapat menurunkan kejadian berat bayi lahir rendah.

Berdasarkan analisis data menunjukan perbandingan ukuran LILA sebelum PMT-P pada ibu hamil dan setelah PMT-P diberikan selama 90 hari, menunjukan tidak ada ukuran LILA ibu hamil yang berkurang setelah PMT-P. Sebanyak 103 ibu hamil mengalami pertambahan ukuran LiLA setelah PMT-P dan 6 ibu hamil dengan tidak ada penambahan ukuran LILA. Hasil Uji Wilcoxon menunjukan nilai significancy $0,001 \quad(p<0,05)$ dengan demikian dapat disimpulkan terdapat perbedaan yang bermakna ukuran LILA sebelum PMT dan setelah PMT pada Ibu Hamil KEK.

Sebagian kecil ibu hamil yang mendapatkan PMT-P tidak mengalami perubahan pada ukuran LiLA selama mendapatkan PMT-P, hal ini kemungkinan dikarenakan ibu yang tidak rutin mengkonsumsi makanan tambahan, ataupun asupan gizi pokok baik kuantitas maupun kualitas masih belum memenuhi standar asupan gizi seimbang, ataupun faktor karakteristik ibu berdasarkan usia serta gaya hidup ibu yang tidak sehat.

Penelitian yang dilakukan di Yogyakarta tentang pengaruh PMT-P pada ibu hamil terhadap berat lahir bayi dengan jumlah sampel $128 \mathrm{ibu}$ hamil didapatkan hasil rerata berat lahir bayi pada kelompok perlakuan adalah $3.248 \mathrm{~g}$ dan kelompok pembanding $2.974 \mathrm{~g}$ dengan perbedaan rerata berat lahir bayi sebesar $274 \mathrm{~g} \quad(\mathrm{p}=0,0002$; 95\%CI:131-416) sehingga PMT-P terbukti secara signifikan berpengaruh terhadap berat lahir bayi. ${ }^{20}$

Begitu juga dengan penelitian di wilayah kerja Puskesmas Banyuanyar tentang analisis pengaruh pemberian makanan tambahan terhadap perubahan status gizi ibu hamil trimester III dengan menggunakan quasi-eksperimenal dan rancang bangun NonEquivalent Control Group dengan besar sampel $30 \mathrm{ibu}$ hamil trimester III yang dibagi menjadi 2 kelompok yaitu kelompok perlakuan dan kelompok kontrol. Untuk melihat berat badan dan perbedaan LiLA menggunakan uji t-tes berpasangan. Hasil penelitian didapatkan pada kelompok perlakuan ada perbedaan signifikan pada perubahan LiLA ibu hamil dengan nilai sig.p=0.029. Sedangkan pada kelompok kontrol tidak ada perbedaan signifikan pada perubahan LiLA ibu hamil bulan pertama dengan nilai sig. $p=0,334 .^{21}$

Penelitian di Puskesmas Kota Surabaya untuk mengetahui perbedaan asupan energi dan protein setelah program 
PMT-P terhadap keberhasilan perbaikan status gizi ibu hamil, dengan menggunakan rancangan penelitian mixed method dengan strategi triangulasi konkuren. Teknik pengambilan sampel penelitian kuantitatif adalah consecutive sampling, dengan responden $47 \mathrm{ibu}$ hamil KEK, partisipan penelitian kualitatif diambil secara purposive sampling. Analisis data kuantitatif diolah dengan uji Mann-Whitney, menunjukkan hasil bahwa program PMT-P pada ibu hamil KEK hanya mampu memperbaiki status gizi menjadi normal sebesar 13\%. Asupan energi dan protein ibu hamil KEK setelah program PMT-P mampu mengubah status gizi menjadi normal sebesar 20\%. Tidak terdapat perbedaan asupan energi dan protein setelah program PMT-P terhadap status gizi ibu hamil KEK dan normal $(p>0,05) .{ }^{22}$

Berdasarkan hasil analisis yang didapat, efektivitas program PMT-P pada ibu hamil KEK di Kota Palembang dipengaruhi oleh input dan proses dari program PMT-P tersebut. Komponen input yang berpengaruh terhadap program PMT-P pada ibu hamil KEK di Kota Palembang yaitu data, sumber daya, dan sasaran. Untuk melengkapi komponen data diperlukan penambahan karakteristik ibu hamil pada laporan program PMT-P pada ibu hamil KEK seperti tinggi badan, jarak kelahiran, berat badan sebelum hamil, serta berat bayi saat lahir. Sehingga dapat di ketahui faktor penyebab terjadinya KEK dan sejauh mana pengaruh ibu hamil KEK terhadap berat bayi saat lahir. Selain itu juga diperlukan keseragaman format laporan dari semua puskesmas yang ada di Kota Palembang, sehingga data dapat diolah dengan baik dan dapat menilai efektifitas pelaksanaan program PMT pada Ibu Hamil KEK.

Penelitian di Burkina Faso pada 1.175 wanita hamil menunjukan bahwa suplemen makanan yang diperkaya dengan energi dan protein pada ibu hamil memiliki panjang bayi saat lahir secara signifikan lebih tinggi (+4.6 $\mathrm{mm} ; \mathrm{P}=0.001$ ) dibanding ibu hamil yang tidak mendapatkan suplemen makanan yang diperkaya dengan energi dan protein dan menghasilkan berat lahir bayi sedikit lebih berat $(+31 \mathrm{~g} ; \mathrm{P}=0,197) .{ }^{23}$ Sebuah penelitian di Dhaka yang bertujuan untuk membandingkan berat badan bayi lahir dari ibu hamil KEK di daerah NNP (National Nutrition Program) dan di daerah yang tidak NNP menunjukan hasil bahwa ibu hamil di daerah NNP empat kali lebih mungkin melahirkan bayi dengan berat badan normal $\mathrm{OR}=3,84$ dengan $\mathrm{CI}$ 95\% (2,01-7,34) dibandingkan ibu di daerah tidak NNP. ${ }^{24}$

Penelitian di Madura, menunjukan bahwa anak-anak dari wanita hamil yang mendapatkan makanan tambahan (High Energy/HE) secara signifikan lebih berat dibandingkan anak-anak dari ibu yang tidak mendapatkan makanan tambahan (Low Energy/LE) $(\mathrm{p}<0,05)$. Anak-anak HE juga lebih tinggi selama 5 tahun pertama $(\mathrm{p}<0,005)$ dari $15-48$ bulan dan $\mathrm{p}<0,05$ pada 3-12 (60 bulan). Wanita usia reproduksi yang mengalami Kekurangan Energi Kronis dan mendapatkan

makanan tambahan/multivitamin selama 90 hari saat trimester akhir kehamilan efektif dalam mengurangi malnutrisi pada anak prasekolah. $^{25}$ Kekurangan Energi Kronis telah menyebabkan banyak masalah selama kehamilan terutama selama periode pertama kehamilan. ${ }^{26}$ Ibu yang Kekurangan Energi Kronis seringkali memiliki anak yang kekurangan gizi. KEK pada ibu hamil di negara-negara berkembang bertanggung jawab untuk 1 dari 6 kasus dengan berat badan lahir rendah. ${ }^{27}$

Terkait sumber daya diperlukan penambahan petugas gizi puskesmas dan pembagian tugas antara petugas gizi dengan bidan KIA yang berkaitan langsung dengan sasaran. Saat ibu hamil melakukan kunjungan kehamilan di bagian KIA, dan terdeteksi berisiko KEK dapat langsung di rujuk ke petugas gizi puskesmas. Sehingga ibu hamil KEK dapat langsung ditangani oleh petugas gizi untuk mendapatkan PMT-P, dan 
mendapatkan konseling mengenai gizi ibu hamil dan juga risiko berat badan bayi lahir rendah dapat dikurangi.

Penelitian di Kota Amritsar India menunjukan hasil analisis bivariat bahwa kontak dengan petugas kesehatan meupakan salah satu faktor yang secara statistik mempengaruhi defisiensi energi kronis di antara wanita. Namun, analisis regresi multivariat hanya melek huruf sebagai faktor signifikan yang mempengaruhi status gizi wanita(OR=0,31, CI=0,11-0,83, $\mathrm{p}=0,03){ }^{28}$

Sedangkan pada proses PMT-P pada Ibu hamil KEK semua komponen mempengaruhi efektivitas program. Proses program PMT-P pada Ibu Hamil KEK dimulai dari perencanaan hingga penilaian. Pada perencanaan diperlukan penetapan target/sasaran yang spesifik serta tujuan yang ingin dicapai. Sehingga akan terbentuk format pelaksanaan program, cara pengawasaan, sampai metode penilaian dari program tersebut.

Pelaksanaan, pengawasaan, dan penilaian PMT-P akan terkait dengan rencana yang telah diterapkan oleh Dinas Kesehatan Kota Palembang. Apabila perencanaan dirancang dan ditetapkan dengan baik maka

\section{DAFTAR PUSTAKA}

1. Sulistyoningsih, H. Gizi untuk Kesehatan Ibu dan Anak. Yogyakarta : Graha Ilmu. 2011

2. Ahmed, F., Tseng. and Marilyn. Diet and Nutritional Status During Pregnancy Public Health Nutrition: Journal Public Health Nutrition 2013. 16(8): 1337-9.

3. Abu, S.K., and Fraser. D.,. Maternal Nutrition and Birth Outcomes. Oxford Journal. 2010. 32(1): 5-25.

4. Mahirawati dan Kartika V. FaktorFaktor yang Berhubungan dengan Kekurangan Energi Kronis (KEK) pada Ibu Hamil di Kecamatan Kamoning dan Tambelangan, Kabupaten Sampang, Jawa Timur. Buletin Penelitian Sistem Kesehatan. 2014. 17:193-202.

5. Departemen Kesehatan RI. Pedoman Penanggulangan Ibu Hamil Kekurangan untuk penilaian dan pengawasaanpun akan lebih mudah, karena mengacu pada pedoman yang telah ditetapkan pada proses perencanaan sebelumnya.

\section{KESIMPULAN DAN SARAN}

Pelaksanaan program PMT-P pada ibu hamil KEK memberikan hasil yang baik terhadap perubahan status gizi ibu hamil. Hasil Uji Wilcoxon menunjukan terdapat perbedaan yang bermakna ukuran LILA sebelum PMT-P dan setelah PMT-P diberikan selama 90 hari.

Saran dari penelitian ini adalah perlu penambahan karakteristik ibu dalam laporan program PMT-P pada Ibu Hamil KEK yang terkait dengan usia kehamilan, paritas, dan berat bayi saat lahir, untuk melihat keterkaitan status gizi ibu hamil dan dampak dari pemberian PMT-P pada ibu hamil KEK. Adanya kerjasama dengan kader dalam hal pengawasaan terhadap ibu hamil yang mendapatkan makanan tambahan, apakah benar-benar mengkonsumsi sesuai dengan anjuran yang diberikan dan evaluasi secara rutin setelah program PMT-P selesai dilaksanakan.

Enargi Kronis. Direktorat Pembinaan Kesehatan Masyarakat. Jakarta : Departemen Kesehatan RI.2002.

6. Damajanti, M., dkk. Pedoman Penanggulangan Kurang Energi Kronik Pada Ibu Hamil. Departemen Kesehatan Republik Indonesia, Editor. Jakarta : Direktorat Bina Gizi. 2015.

7. Arisman. Gizi dalam Daur Kehidupan: Buku Ajar Ilmu Gizi. Jakarta : EGC. 2014.

8. Ekowati, D., High Parity and Chronic Energy Deficiency Increase Risk for Low Birth Weight in Situbondo District. Journal Public Health and Preventive Medicine Archive. 2017. (https://ojs.unud.ac.id/index.php/phpma/ article/view/32503.

9. Djamilah, A., Faktor-Faktor yang Berhubungan dengan KEK pada Ibu 
Hamil di Wilayah Puskesmas Jembatan Serong, Kecamatan Pancoran Mas Depok Jawa Barat, Skripsi.FKM Universitas Indonesia. Jakarta. 2008.

10. Opara, J., Malnutrition During Pregnancy Among Child Bearing Mothers in Mbaitolu of Imo State. Nigeria. Mediteranean Journal of Social Science, 2011. 2 (6).

11. Selvakumar, D.L., Relationships Between A Prenatal Nutrition Education Intervention and Maternal Nutrition in Ethiopia. Dissertations. 2015 College of Social and Behavioral Sciences. Public Policy and Administration Faculty. Walden University.

12. Riset Kesehatan Dasar. Jakarta : Kemenkes RI. 2007.

13. Dinkes Kota Palembang. 2016. Profil Kesehatan Kota Palembang Tahun 2015.

14. Kementerian Kesehatan RI, Petunjuk Teknis Pemberian Makanan Tambahan Ibu Hamil. Kementerian Kesehatan Jakarta. 2010.

15. Sugiyono. Metode Penelitian Kombinasi (Mixed Methode). Alfabeta: Bandung.

16. Nurina, R., 2016. Program Pemberian Makanan Tambahan untuk Peningkatan Status Gizi Ibu Hamil dan Balita di Kecamatan Cilamaya Kulon dan Cilamaya Wetan, Karawang. Jurnal Resolusi Konflik, CSR. 2012. 1(1): 449.

17. Prawita, A., Susanti, A.I., dan, P. Survei Intervensi Ibu Hamil Kurang Energi Kronik (KEK) di Kecamatan Jatinangor. Jurnal JSK. 2017; 2(4): 186-191.

18. Gao, H., Stiller, CK., Scherbaum,V., Biesalski, HK., Wang, Q., Hormann, E. et al. Dietary Intake and Food Habits of Pregnant Women Residing in Urban and Rural Areas of Deyang City, Sichuan Province, China. Journal Nutrients 2013; 5(8): 2933-54.

19. Prihananto, V., Sulaeman, A., Riyadi, H., dan Palupi, N.H.S. 2007. Pengaruh Pemberian Makanan Tambahan terhadap Konsumsi Energi dan Protein Ibu Hamil. Jurnal Gizi dan Pangan. 2(1): 16-21.

20. Zulaidah, H.S., Kandarina. I., Hakimi, M. Pengaruh Pemberian Makanan Tambahan (PMT) pada Ibu Hamil Terhadap Berat Lahir Bayi. Jurnal Gizi klinik Indonesia UGM. 2014; 11(2): 6171.

21. Wahida. Z.F., Pengaruh Pemberian Makanan Tambahan terhadap Perubahan Status Gizi Ibu Hamil, Jurnal Keperawatan dan Kebidanan - Stikes Dian Husada Mojokerto, Jurnal Keperawatan dan Kebidanan Stikes Dian Husada Mojokerto. 2015; 7(1): 8999.

22. Nugrahini, E.Y., Effendi, J.S., Herawati, D.M.D., Asupan Energi dan Protein Setelah Program Pemberian Makanan Tambahan Pemulihan Ibu Hamil Kurang Energi Kronik di Puskesmas Kota Surabaya, JEMC. 2014; 1(1).

23. Huybregts, L., Roberfroid. D., Lanou. H., Menten. J., Meda. N., Camp. J.V., and Kolsteren. P., Prenatal Food Supplementation Fortified with Multiple Micronutrients Increases Birth Length: a Randomized Controlled Trial in Rural Burkina Faso. American Journal of Clinical Nutrition. 2009; 90(6):1593600.

24. Karim, M.R., Flora. M.S., Akhter. S., Birthweight of The Babies Delivered by Chronic Energy Deficient Mothers in National Nutrition Program (NNP) Intervention Area. Journal Bangladesh Med Res Counc Bull. 2011; 37; 17-23.

25. Kusin, J.A., Kardjati. S., Houtkooper. J.M., Renqvist. U.H., Energy Supplementation During Pregnancy and Postnatal Growth, Journal and Books the Lancet. 1992; 340(8820): 623-6.

26. Opara, J.A., Helen, E., Adebola, N., Kasiobi. S., Oguzor., and Sodienye, A., Malnutrition during Pregnancy among Child Bearing Mothers in Mbaitolu of Imo State Nigeria, Mediteranean Journal of Social Science. 2011; 2(6). 90-6.

27. The Lancet. Maternal and Child Nutrition. Executive Summary of the Lancet Maternal and Child Nutrition Series. 2011.

28. Devgun, P., Mahajan, S.L., Gill. K.P., $X$. Prevalence of Chronic Energy Deficiency and Socio Demographic Profile of Women in Slums of Amritsar City, Punjab, India. Int $\mathbf{J}$ Res Health Sci. 2011; 2(2):527-32. 